\title{
Two new Marquesan species of the southeastern Polynesian genus Oparanthus (Asteraceae, Coreopsidinae)
}

\author{
Warren L. Wagner', David H. Lorence ${ }^{2}$ \\ I Department of Botany, MRC-166, Smithsonian Institution, P. O. Box 37012, Washington, DC 20013- \\ 7012) 2 National Tropical Botanical Garden, 3530 Papalina Road, Kalaheo, HI 96741 \\ Corresponding author: Warren L. Wagner(wagnerw@si.edu) \\ Academic editor: Vicki Funk | Received 26 May 2011 | Accepted 15 June 2011 | Published 12 July 2011 \\ Citation: Wagner WL, Lorence DH (2011) Two new Marquesan species of the southeastern Polynesian genus \\ Oparanthus (Asteraceae, Coreopsidinae). In: Lorence DH, Wagner WL (Eds) Botany of the Marquesas Islands: new taxa, \\ combinations, and revisions. PhytoKeys 4: 139-148. doi: 10.3897/phytokeys.4.1603
}

\begin{abstract}
Two new species of the recently revised genus Oparanthus (Asteraceae, Subtribe Coreopsidinae) were discovered during the National Tropical Botanical Garden/Smithsonian Institution 1997 expedition to the Marquesas Islands. Oparanthus woodii W. L. Wagner \& Lorence, sp. nov. is known from a single population on the island of Nuku Hiva, and O. tiva W. L. Wagner \& Lorence, sp. nov. is known only from Tahuata. Small domatia with a tuft of hairs occur in $O$. tiva (and the previously known O. hivoanus), and similar but naked domatia are found occasionally in $O$. woodii. Domatia are of exceedingly rare occurrence in Asteraceae. Both new species are extremely rare and are considered critically endangered (CR) as are the other four species of the genus.
\end{abstract}

\section{Keywords}

Asteraceae, conservation, French Polynesia, Marquesas Islands, Oparanthus

\section{Introduction}

Ongoing investigation of the vascular flora of the Marquesas Islands has been facilitated through a collaboration between National Tropical Botanical Garden (NTBG), Smithsonian Institution (SI), and the Délégation à la Recherche Papeete, Tahiti, French Polynesia. One of the expeditions in 1997 resulted in the discovery of two additional species of the genus Oparanthus Sherff, of which there are two previously 
known Marquesan species and two from Rapa Island (Shannon and Wagner 1997). They are described and illustrated and their conservation status is assessed in this paper.

Since the most recent revision of the genus (Shannon and Wagner 1997) new studies of the phylogeny and biogeography of Oparanthus have been completed. Fitchia Hook. f., Oparanthus, and Petrobium R. Br. have been considered to be insular derivatives from the genus Bidens L. (Carlquist 1974; Shannon and Wagner 1997). These relationships were not supported by ITS study of the Coreopsideae by Kimball and Crawford (2004). According to their phylogenetic results Fitchia and Oparanthus are sister genera and share a common ancestor with two Caribbean genera, Narvalina Cass. and Selleophytum Urb. Another study was initiated (H. Dempewolf, T. Motley, D. Lorence and W. Wagner unpubl.) to further examine the biogeographic patterns in this lineage of two genera with no affinities to other Pacific Asteraceae but which represent an interesting biogeographic disjunction with two genera of the Caribbean. This unpublished phylogenetic analysis of Oparanthus and Fitchia utilized nuclear ribosomal gene regions (ITS, ETS, and 5S-NTS). The results of the analyses of four species of Fitchia (of eight) and five species of Oparanthus (of six) indicate a strongly supported relationship between the two genera and, at least among the extant species, it appears that a Fitchia/Oparanthus ancestor first colonized Rapa. This makes sense because Rapa is at the young end of a series of hot-spot traces in southern Polynesia (McNutt et al. 1997). Rapa is about 4.1-4.8 Ma, but the volcanic chains in this region date back to 34-35 Ma (McNutt et al. 1997; Bonneville et al 2002) allowing for the possibility of colonization much earlier than the age of any islands that either genus occurs on presently (i.e., the Societies, Marquesas, Rapa, and Rarotonga).

To date only 47 total collections of Oparanthus have been made of the four Marquesan species, which gives an indication of how uncommon they are. Collections of two of the species, $O$. hivoanus and $O$. teikiteetinii, consititute the bulk (36). Both of these species occur as scattered individuals in appropriate habitat or are occasionally relatively common in localized areas. The two new species described here are known from only a few collections. When evaluated using the IUCN criteria for endangerment (IUCN 2001) all four of the Marquesan species of Oparanthus fall into the Critically Endangered (CR) category, which designates species facing the highest risk of extinction in the wild. Marquesan species of Oparanthus meet the IUCN criteria by having known ranges less than $100 \mathrm{~km}^{2}$, an area of occupancy of less than $10 \mathrm{~km}^{2}$, continuing decline in the quality of habitat.

\section{Methodology}

All measurements given herein are taken from dried herbarium specimens, although certain features such as shapes were supplemented with information from alcoholpreserved flowers, field notes, and color slides or digital photos. Measurements are presented in the descriptions as follows: length $\times$ width, followed by units of measurement $(\mathrm{mm}$ or $\mathrm{cm})$. Specimens from the following herbaria were studied: BISH, K, MO, NY, P, PAP, PTBG, and US. 
The new species described here fit well in the sectional classification developed prior to their discovery (Shannon and Wagner 1997). Plants of Oparanthus sect. Albiflori, which includes all four Marquesan species, are characterized by leaves relatively thin to slightly thickened and subcoriaceous, marginal veins obscure or inconspicuous, the involucral bracts in 2-3 well defined series, corollas white, and achene wings and awns glabrous.

\section{Key to species of Oparanthus in the Marquesas Islands}

1a Plants hirsute, especially on inflorescences and young shoots and leaves; domatia never present in abaxial primary leaf axils................ O. teikiteetinii

$1 \mathrm{~b} \quad$ Plants glabrous or nearly so; domatia nearly always present in abaxial primary

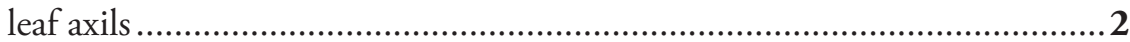

2a Heads solitary; ray floret corolla tube and throat 7.5-8 mm long; leaf bases connate around stem; domatia present or absent in abaxial leaf axils, without associated hairs O. woodii

2b Heads in clusters of 3; ray floret corolla tube and throat 3-4 mm long; leaf bases not connate around stem; domatia present in abaxial leaf axils, covered with hairs

3a Trees 3-7 m tall; leaves thinly coriaceous, $10-19.3 \times 6-15.8 \mathrm{~cm}$; heads 9-14 $\mathrm{mm}$ in diameter, $10-20 \mathrm{~mm}$ high; receptacular bracts of ray florets $10-11$ $\mathrm{mm}$ long, those of disk florets $12-13 \mathrm{~mm}$ long; sterile disk achenes $12-13 .$.

O. tiva

3b Shrubs; leaves subcoriaceous, $2.3-8 \times 1.3-4.5 \mathrm{~cm}$, on young shoots up to 13 $\mathrm{cm}$ long and $11 \mathrm{~cm}$ wide; heads $7-12 \mathrm{~mm}$ in diameter, 9-13 $\mathrm{mm}$ high; receptacular bracts of ray florets $7.5-8 \mathrm{~mm}$ long, those of disk florets $9-11 \mathrm{~mm}$ long; sterile disk achenes ca. 20

O. hivoanus

\section{Oparanthus tiva W. L. Wagner \& Lorence, sp. nov.}

urn:lsid:ipni.org:names:77112740-1

http://species-id.net/wiki/Oparanthus_tiva

Fig. 1, 3C

Ab O. hivoano foliis tenue coriaceis, 10-19.3 $\times 6-15.8 \mathrm{~cm}$, testibus 9-14 mm diametro, 10-20 mm altis, paleis flosculorum radiorum 10-11 mm longis, paleis flosculorum discorum 12-13 mm longis, 12-13 achenis sterili disci differt.

Type. Marquesas Islands: Tahuata, ridge E of trail ridge up to Amatea from Kuaee, E facing slope, $2560 \mathrm{ft}$ (780 m), 18 July 1997, S. P. Perlman, K. R. Wood, and J. P. Luce 16008 (Holotype: PTBG-025572!; isotypes: BISH!, P!, PAP!, US!). 


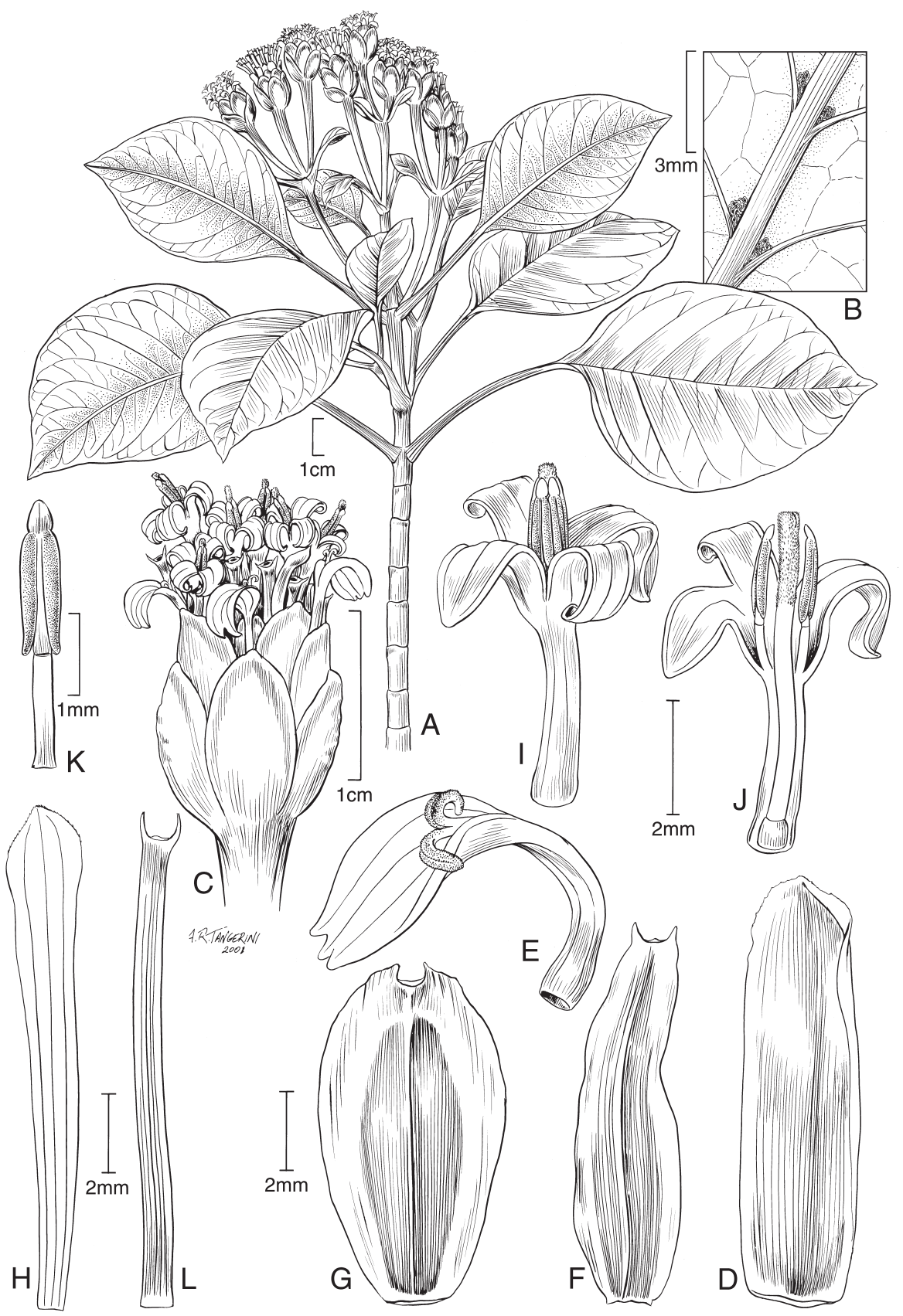

Figure I. Oparanthus tiva W. L. Wagner \& Lorence. A-C drawn from Perlman et. al 15997, US A flowering branch $\mathbf{B}$ abaxial leaf surface showing domatia with associated tuft of hairs in axils of primary veins C head; D-L drawn from spirit-preserved material of type collection, Perlman et. al. 16008, PTBG; D receptacular bract of ray floret $\mathbf{E}$ ray corolla and functional style $\mathbf{F}-\mathbf{G}$ ray achene $\mathbf{H}$ receptacular bract of disk floret I disk corolla with non-functional style and fertile stamens J longitudinal view of disk corolla with non-functional style and fertile stamens $\mathbf{K}$ fertile stamen from disk floret $\mathbf{L}$ sterile disk achene. 
Description. Trees 3-7 $\mathrm{m}$ tall, subglabrous, functionally monoecious, the main trunk to $30 \mathrm{~cm}$ in diameter, often with multiple prop roots, bark brown, wood cream colored, the young stems with short internodes. Leaves thinly coriaceous, the blade ovate to very broadly ovate, $10-19.3 \times 6-15.8 \mathrm{~cm}$, the young ones often viscous and with a turpentine-like scent, secondary veins $6-18 \mathrm{~mm}$ apart, abaxial axils with domatia with small tufts of hairs, margins weakly dentate to subentire, apex bluntly acuminate to obtuse, base obtuse to occasionally truncate, often oblique; petioles $3-9 \mathrm{~cm}$ long. Inflorescences terminal, heads in clusters of 3, 9-14 $\mathrm{mm}$ in diameter, 10-20 mm high; peduncles 15-76 mm long; involucre campanulate, the bracts 7-9, in 2 series, 7-11 mm long, the external ones wider and thicker; receptacular bracts of ray florets $10-11 \mathrm{~mm}$ long, those of disk florets $12-13 \mathrm{~mm}$ long; ray florets $8-10$ in 1-3 series, white, corolla tube and throat 3-4 mm long, limb 3-3.8 mm long, shallowly toothed; disk florets 18-20, white, corolla tube and throat 3.5-4 mm long, the lobes $3 \mathrm{~mm}$ long. Ray achenes 8-9 $\mathrm{mm}$ long, narrowly elliptic to lanceolate, winged on both margins, the wings up to $1 \mathrm{~mm}$ wide, the wing margin smooth, extending beyond the achene apex; the disk achenes sterile, linear, $12-13 \mathrm{~mm}$ long.

Etymology. We are pleased to name this new species in recognition of its first collector, Steven P. Perlman, known in the Marquesas by his nickname "Tiva", in recognition of his contributions to our knowledge of the flora of the Pacific region.

Distribution. Endemic to the Marquesas Islands and restricted to the vicinity of the type locality on Tahuata.

Ecology. Scattered to locally common in the low wet forest, dominated by species of Alsophila, Crossostylis, Freycinetia, Hibiscus, Metrosideros, Reynoldsia, and Weinmannia, with an understory rich in plants such as Cyrtandra, Dicranopteris, Gahnia, Macropiper, Marattia, Morinda, and Psychotria, from 790 to $900 \mathrm{~m}$ elevation, usually on windswept slopes and gulches of summit areas. Known to flower and fruit in July.

Conservation status. Following the criteria and categories of IUCN (2001) it is assigned a preliminary status of Critically Endangered (CR): B2a, B2b (i-iii); D: B2: total area of occupancy less than $10 \mathrm{~km}^{2}\left(\mathrm{ca} .5 \mathrm{~km}^{2}\right)$. B2a, a single population known; b (i-iii), habitat continuing decline inferred; D, population estimated to number fewer than 250 individuals. The suitable habitat for Oparanthus tiva on Tahuata (c. 61 $\mathrm{km}^{2}$ ) is indicated as an endangered environment, threatened feral animals and invasive plants, reducing the extent of the forest. The known habitat is not pristine and nonnative plants such as Ageratum conyzoides L., Elephantopus mollis Kunth, Melinis repens (Willd.) Zizka, Paspalum conjugatum P. J. Bergius, Paspalum paniculatum L., Psidium guajava L., Spathoglottis plicata Blume, and Zingiber zerumbet (L.) Sm. were observed in the area.

Specimen examined. Marquesas Islands: Tahuata: ridge from Amatea to Moteve passing Meikaea, view down is on village of Hanatetena, on E facing slope, Perlman et al. 15977 (BISH, P, PAP, PTBG, US); off trail from Amatea to Moteve, above Haaoipu Bay, to NE of Hanatetena, top of ridge crest, W facing slope, Perlman et al. 15998 (PTBG); Haaoiputeomo summit region, upper drainage to $\mathrm{N}$ of satellite dish, [09 56'S, 139 04'W], Wood 6523 (BISH, MO, NY, P, PAP, PTBG [2], US); Amatea 
region, locations around Haaoiputeomo satelite dish (parabowl), Wood 10263 (PAP, PTBG, US), Wood 10265 (PAP, PTBG, US).

Discussion. Oparanthus tiva has domatia (with an associated tuft of hairs) on the abaxial surface of the leaves. Domatia are essentially absent in the family, so domatia in $O$. tiva should be investigated further to understand the ecological significance. When domatia were discovered in $O$. tiva, we reexamined the other species of the genus and those of the closely related genus Fitchia. We found them only in the closest relative, $O$. hivoanus and in the Nuku Hiva species, O. woodii, but in these without the associated tuft of hairs covering the pit. Oparanthus tiva is a relatively rare species with an estimated 100 individuals known. It is distinguished from $O$. hivoanus by the tree habit, leaves thinly coriaceous, $10-19.3 \times 6-15.8 \mathrm{~cm}$, larger heads $9-14 \mathrm{~mm}$ in diameter, 10-20 mm high, receptacular bracts of ray florets $10-11 \mathrm{~mm}$ long, those of disk florets 12-13 $\mathrm{mm}$ long, and the sterile disk achenes 12-13.

\section{Oparanthus woodii W. L. Wagner \& Lorence, sp. nov.}

urn:1sid:ipni.org:names:77112741-1

http://species-id.net/wiki/Oparanthus_woodii

Fig. 2, 3D

Ab O. teikiteetinii fere glabra arbore, domatiis apilosis in foliis abaxialibus in axilibus nervis secundariis presentibus, foliis basi connatis, flosculis radiorum tubis corollarum 7.5$8 \mathrm{~mm}$ differt.

Type. Marquesas Islands: Nuku Hiva: Ooumu region, top of Tapueahu Valley off new Hwy, [08 51'53S, 140 10'63W], 1067-1128 m, 23 June 1997, K. R. Wood 6375 (Holotype: PTBG-025565!; isotypes: BISH!, P!, PAP!, US!).

Description. Trees 2-5 m tall, glabrous, functionally monoecious, moderately to diffusely branched, the trunk often with multiple prop roots, bark brown, wood cream-colored. Leaves thinly coriaceous, the blade broadly elliptic to broadly ellipticobovate, $11-23.1 \times 3.5-12.7 \mathrm{~cm}$, secondary veins 4-12 mm apart, conspicuously arching upward from midrib, then spreading to margin, abaxial axils often with domatia, these without associated hairs, margins entire, apex rounded to truncate, base cuneate, often oblique; petioles 3.5-6 cm long, the base conspicuously connate around stem with paired leaf petiole. Inflorescences terminal, heads solitary, $12-16 \mathrm{~mm}$ in diameter, 22-35 mm high, peduncles 3-15 mm long, stout; involucre campanulate; involucral bracts 8 , in 2 series, the external ones $8-13 \mathrm{~mm}$ long, connate at the base, thick and broadly triangular, becoming lignified in fruit, the internal ones usually longer (up to $15 \mathrm{~mm}$ ) and narrower, triangular to elliptic; receptacular bracts of the ray florets 13-14 $\mathrm{mm}$ long, those of the disk florets $12-13 \mathrm{~mm}$ long; ray florets ca. 18-22, in 2 series, corolla tube and throat 7.5-8 $\mathrm{mm}$ long, limb 4.2-4.5 $\mathrm{mm}$ long, 2-3-lobed, the lobes usually divided to near corolla throat, occasionally only shallowly so; disk florets ca. 40-50 or perhaps more, corolla tube and throat 6.3-6.6 $\mathrm{mm}$ long, the lobes 4.4-5.4 


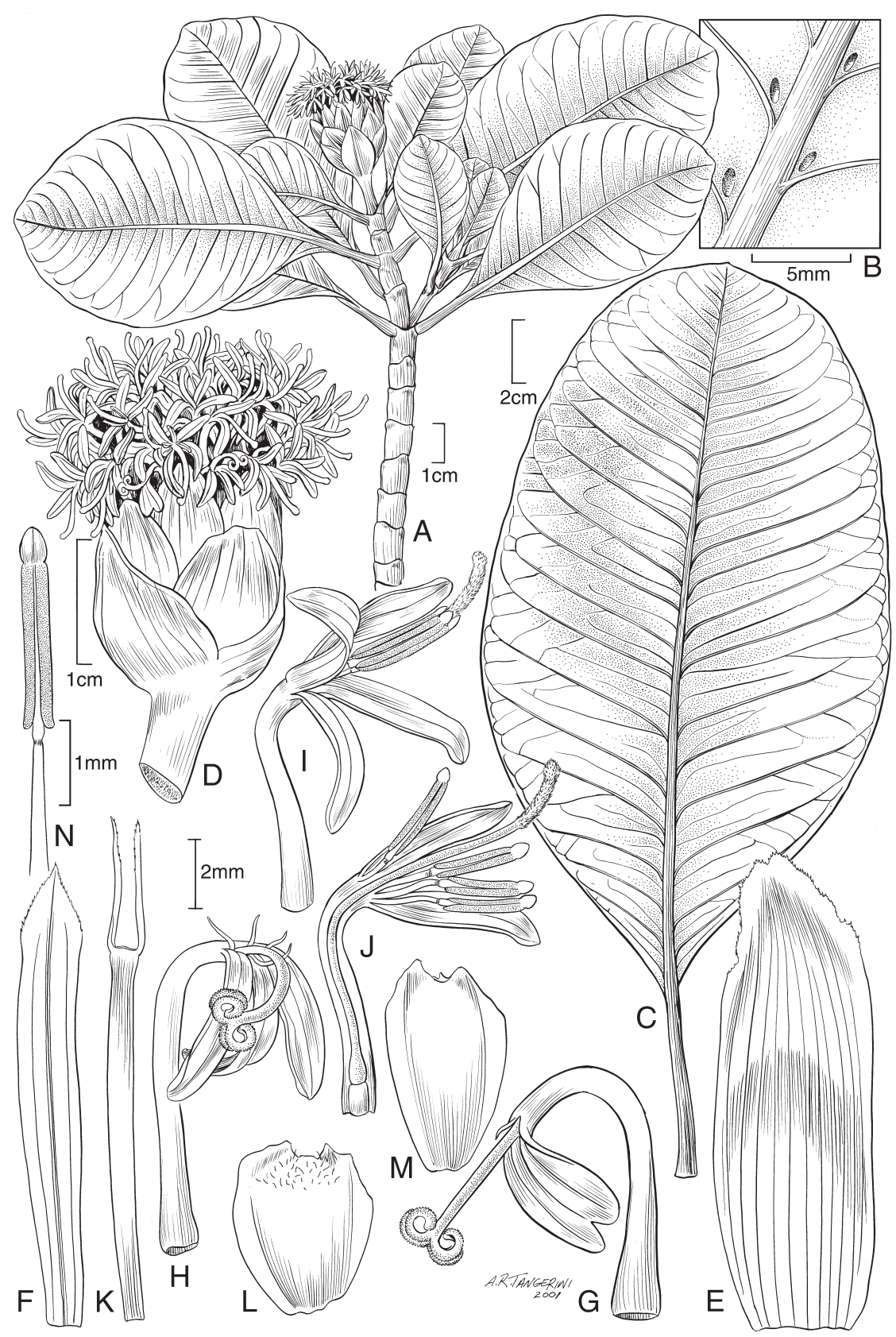

Figure 2. Oparanthus woodii W. L. Wagner \& Lorence. A-N drawn from holotype Wood 6375, PTBG, except B from US isotype. A flowering branch B abaxial leaf surface showing naked domatia in axils of primary veins $\mathbf{C}$ lower leaf $\mathbf{D}$ head $\mathbf{E}$ receptacular bract of ray floret $\mathbf{F}$ receptacular bract of disk floret G-H ray corolla and functional style I disk corolla with non-functional style and fertile stamens J longitudinal view of disk corolla with non-functional style and fertile stamens $\mathbf{K}$ sterile disk achene $\mathbf{L}-\mathbf{M}$ ray achenes $\mathbf{N}$ fertile stamen from disk floret. 


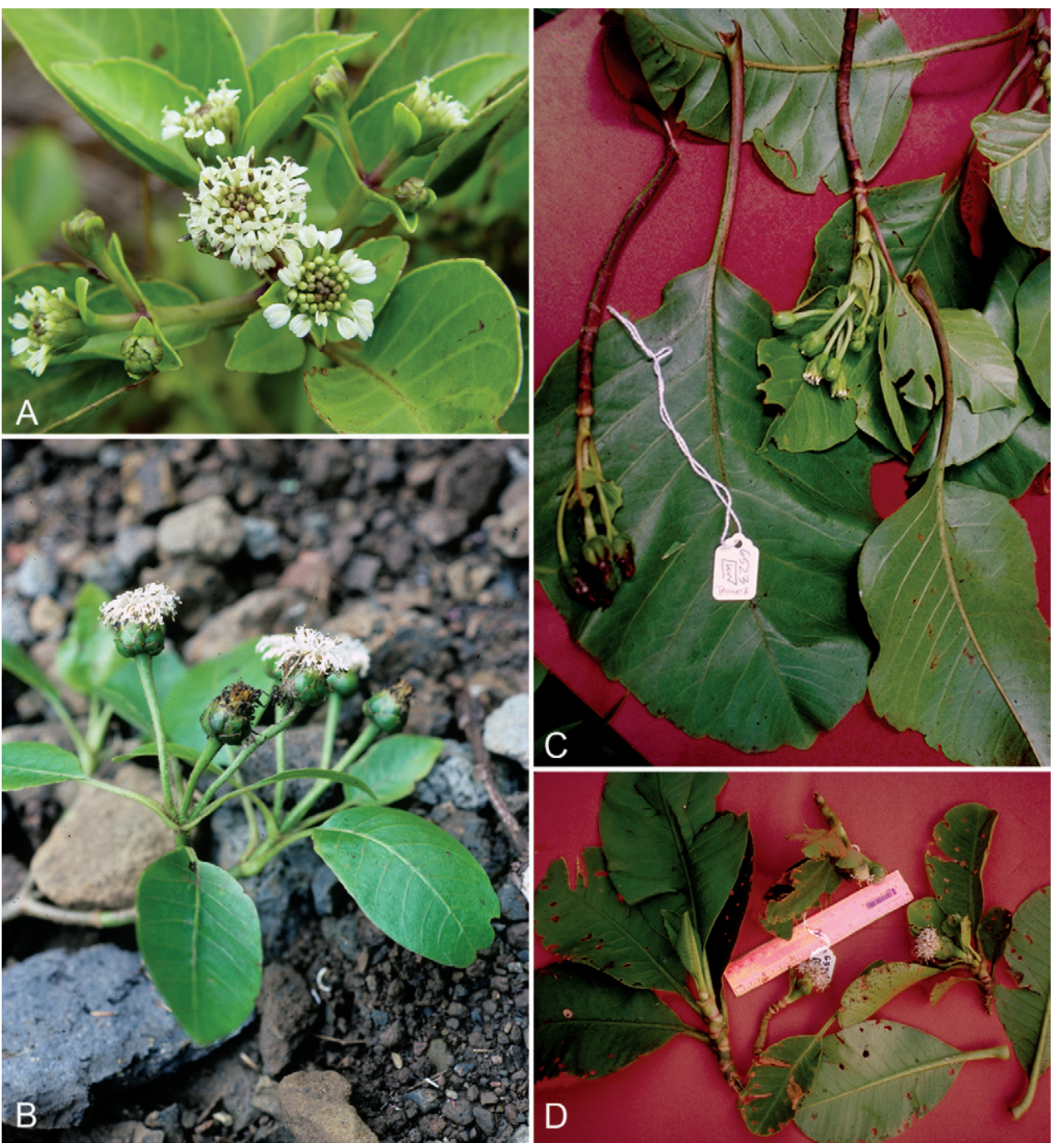

Figure 3. Field images of Oparanthus. A O. hivaoanus, (Hiva Oa, Price et al 201, photo D. Lorence) B O. teikiteetinii (Nuku Hiva, Lorence 6078, photo D. Lorence) C O. tiva (Tahuata, Wood 6523, photo K. Wood) D O. woodii (Nuku Hiva, Wood 6338, photo K. Wood).

$\mathrm{mm}$ long. Ray achenes elliptic, 5-6 mm long, distinctly winged, the wings ca. $1 \mathrm{~mm}$ wide, extending slightly beyond the achene apex; disk achenes sterile, linear, 10-11 mm long, with 2 awns.

Etymology. This new species is named for Kenneth R. Wood, who first collected it and who has contributed greatly to our knowledge of the flora of the Marquesas and Hawaii through his collections and field observations.

Distribution. Endemic to Nuku Hiva, Marquesas Islands, and apparently restricted to the Ooumu region, in gulches near the top of Tapueahu Valley, from 1060 to 1130 m elevation. 
Ecology. Occurring in montane mesic to wet forest, ravines and steep slopes, with Metrosideros and Weinmannia dominant and a diverse understory of Asplenium, Blechmum, Cyrtandra, Hypolepis, Ilex, and Melicope, with stands of Freycinetia nearby. Known to flower in June, but probably for some months after that.

Conservation status. Based on the IUCN criteria and categories this species is assigned a preliminary Red List status of Critically Endangered (CR) B2a, B2b (i-iii); D: B2: total area of occupancy less than $10 \mathrm{~km}^{2}\left(\mathrm{ca} .5 \mathrm{~km}^{2}\right)$. B2a, a single population known; b (i-iii), habitat continuing decline inferred; $\mathrm{D}$, population estimated to number fewer than 250 individuals. The suitable habitat for Oparanthus woodii on Nuku Hiva (c. 340 $\mathrm{km}^{2}$ ) is indicated as an endangered environment, threatened by human activity (deforestation and fire), feral animals, and invasive plants, thus reducing the extent of the forest.

Discussion. Oparanthus woodii appears to be closely related to O. teikiteetinii, which grows at lower elevations, but approaches the known range of $O$. woodii within a few hundred meters. While O. teikiteetinii is generally distinctive in the genus for its large size, attaining heights of up to $12 \mathrm{~m}$, and for its large, often solitary capitula, $O$. woodii is a smaller tree up to $5 \mathrm{~m}$ tall and has large solitary heads on much shorter and stouter peduncles up to $15 \mathrm{~mm}$ long. The corollas are similar in these two species, but the ray corollas of $O$. woodii are also distinctive in that they are deeply divided to near the corolla throat. Likewise the leaves of $O$. woodii are distinctive in that they are conspicuously connate at the petiole bases, have secondary veins that arch upwards, and have naked domatia in the abaxial vein axils. These are not always present and they lack the tufts of hairs in the always present domatia of O. hivoanus and O. tiva.

Specimens examined. Marquesas Islands: MARQUESAS ISLANDS: Nuku Hiva, Ooumu region, top of Tapueahu Valley off new Hwy, [08 51'53S, 140 10'63W], Wood et. al. 6338 (P, PTBG, US); Wood 6376 (PTBG, US); Wood 6377 (BISH, K, P, PAP, PTBG, US).

\section{Acknowledgments}

This study was made possible by field observations, photos, and specimens provided by Ken Wood and Steve Perlman (National Tropical Botanical Garden) as part of the "Vascular Flora of the Marquesas Islands" project, which was supported by a generous private donation. We are grateful to the Délégation à la Recherche (Papeete, Tahiti), the Musée de Tahiti et des Iles, and the Service du Développement Rural for logistic support, the Délégation for permission to collect in the Marquesas, and the Délégation and the Haut-Commissariat de la République en Polynésie française for permission to conduct research. The illustrations were skillfully drawn by Alice Tangerini (Smithsonian Institution). We thank Harold Robinson and Tod Steussey for reviewing the manuscript and useful discussions and Alain Touwaide for translation of the Latin diagnosis. The contribution by WLW to this study was partially supported by the Smithsonian Research Opportunities Fund and while appointed as McBryde Chair at the National Tropical Botanical Garden. 


\section{References}

Bonneville A, Le Suavé R, Audin L, Clouard V, Gillot PY, Janney P, Jordahl K, Maamaatuaiahutapu K (2002) Arago Seamount: The missing hotspot found in the Austral Islands. Geology 30: 1023-1026. doi:10.1130/0091-7613(2002)030<1023:ASTMHF>2.0.CO;2 Carlquist S (1974) Island Biology. Columbia University Press, New York.

IUCN (2001) IUCN Red List categories (version 3.1). IUCN Species Survival Commission, Gland, Switzerland.

Kimball RT, Crawford DJ (2004) Phylogeny of Coreopsideae (Asteraceae) using ITS sequences suggests lability in reproductive characters. Molecular Phylogenetics and Evolution 33: 127-139. doi:10.1016/j.ympev.2004.04.022

McNutt MK, Caress DW, Reynolds J, Jordahl KA, Duncan RA (1997) Failure of plume theory to explain midplate volcanism in the southern Austral islands. Nature 389: 479-482. doi: $10.1038 / 39013$

Shannon RK, Wagner WL (1997) Oparanthus (Asteraceae, subtribe Coreopsidinae) revisited. Allertonia 7: 273-295. 